\title{
UNDERSTANDING COSMOPOLITAN CONSUMERS' REPEAT PURCHASING IN THE EMARKETPLACE: CONTRIBUTION FROM A BRAND ORIENTATION THEORETICAL PERSPECTIVE
}

\author{
Christian Nedu Osakwe, Henry Boateng, Simona Popa, \\ Miloslava Chovancová, Pedro Soto-Acosta
}

\section{Introduction}

Brands, branding, brand management, brand orientation and their related terms have received substantial attention from marketing scholars and practitioners (Peng, Chen, \& Wen, 2014). This could probably be due to their strategic importance to organizations (Urde, Baumgarth, \& Merrilees, 2013). Consumers on the other hand have also come to embrace the concept, as it helps them in their purchasing decisions by offering them signals for improved efficiency in information processing and for selecting products (Kotler \& Pfoertsch, 2007; Shi \& Chow, 2015; Zablah, Brown, \& Donthu, 2010). As a result, organizations and consumers alike tend to become brand oriented (Keller, 2009). Urde (1999) defined brand orientation as a process by which a firm develops, builds and protects a brand and its identity as it interacts with actual and potential customers with the intention of obtaining sustainable competitive advantage(s). This means that brand orientation is meant to achieve a strategic purpose and the central aim of this is to earn a good reputation in the marketplace and, importantly, do so by building good relationships with consumers via communication platforms (Xin, Ramayah, Soto-Acosta, Popa, \& Ping, 2014; Soto-Acosta, Popa, \& Palacios-Marqués, 2016). Given the role of social media sites in our contemporary society, it makes a lot of sense for businesses, and in particular online retailers, to build a 'two-way' symbiotic relationship with their consumers through some of these popular social media platforms (Curras-Perez, Ruiz-
Mafe, \& Sanz-Blas, 2014; Soto-Acosta, Molina-Castillo, Lopez-Nicolas, \& ColomoPalacios, 2014). Again, it can be inferred that engaging customers on a social media site is critical for brand orientation as social media promotes customer-firm (brand) interaction (Boateng, 2014). However, this is yet to be proven empirically and this study seeks to address these gaps. It also seeks to ascertain if consistent engagement with vendors' social media site by consumers will lead to an electronic word-of-mouth - (e)WoM effect. Again, since brand orientation is a resource (Urde et al., 2013), this study aims to find if there is a correlation between brand orientation and reputation of the enterprise (e.g. online retail vendor), which is of great importance to marketing practitioners (Capozzi, 2005).

Some studies (Fombrun, Gardberg, \& Barnett, 2000; Sung \& Yang, 2008) have pointed to the several marketing outcomes of the reputation of the business enterprise, including monetary and non-monetary outcomes. However, it is not clear if these benefits are attainable in an online context. Bartikowski and Walsh (2011) noted that while corporate reputation has attracted considerable attention in marketing discipline and practice, there is a dearth of literature on the effects of corporate reputation on most actions of consumers. For example, can a vendor's reputation lead to (e)WoM effect and draw customers to its social media sites? Does a vendor's reputation influence consumers' repurchase intentions in an online environment? These questions 
require answers, which this study seeks to address. Although, some studies (e.g. Jalkala \& Salminen, 2009) have been conducted in a business-to-business context, AarikkaStenroos and Makkonen (2014) argue that the relevance of the findings might not be same in consumer market and therefore call for more studies to be conducted in a business-toconsumer relationship.

In sum, in this paper, we address research issues connected to the role that brand orientation (potentially) plays in critically influencing the constructs social media site engagement and (online) vendor reputation; the assumption that vendor reputation may also strongly influence the constructs social media site engagement, (e)WoM effect, and repurchase intention is also interrogated. Additionally, this scientific paper tests the assumption about the direct effect of (e)WoM on customers repurchase intention within the context of the electronic marketplace (eMarketplace). Accordingly, the study's major objective is to facilitate the better understanding of the interrelationships amongst the phenomena of brand orientation, (e)WoM effect, social media engagement, vendor reputation, and repurchase intention in the eMarketplace context.

By and large, this scientific publication is grounded in the relationship marketing literature. The remainder of the paper is organised as follows. Section two focuses on the theoretical background of the study, including the research hypotheses, while section three presents the methodology employed. Section four offers the findings, which are discussed in section five. Conclusions, limitations and future research are dealt with in section six.

\section{Theoretical Background and Hypotheses Development \\ 1.1 Brand Orientation (BO) Social Media Site Engagement (SME) and Vendor Reputation (VRP)}

Brands create impressions and emotions and elicit behavioural responses through their unique identity (Brakus, Schmitt, \& Zarantonello, 2009). Whenever consumers come into contact with a brand they form perceptions, and these influence their decision to use the brand, recommend it to others and pay attention to any promotion about it (Ambler et al., 2002). Some studies (e.g. Hutter, Hautz, Dennhardt,
\& Fuller, 2013) argue that consumers continued interaction with a brand contributes to their positive perceptions about the brand. In other words, brand orientation can impact on a vendor's reputation since brand orientation adopts a continued interaction approach with customers to build strong brand identity (Urde, 1999). As a result, some organizations adopt a brand orientation approach where they create, grow and protect the identity of the brands (Urde, 1999). Sahin, Zehir and Kitapaci (2011) found that, brand orientation is positively associated with consumer brand trust. This provides a basis for the effect of brand orientation on a vendor's reputation, since some organizations gain their reputation by being trustworthy (Miyamoto \& Rexha, 2004). A reputable vendor instils trust and confidence in its customers by delivering services as promised and so creates value for its customers (Agustin \& Singh, 2005). Algesheimer, Dholakia and Herrmann (2005), on the other hand argue that, brand relationship quality influences consumers' engagement with a brand community. It is safe, therefore, to argue that brand orientation contributes to consumers' engagement with the social media site of a vendor. Moreover, in another related study by Jayawardhena, Wright and Dennis (2007), the authors presume that online shoppers who are more brand motivated (or oriented) are equally likely to brand-loyal shoppers. Thus, it is expected that these brand oriented (or savvy) consumers would be more inclined to shop with highly reputable online retail vendors. Again, since certain factors incline human beings to bond with other people or objects, customers can bond with a vendor's website; however, this will depend on the reputation of the vendor (Park \& Kim, 2014). Furthermore, King, So and Grace (2013) explored the effect of service brand orientation on the attitude of employees in a hotel and found that service brand orientation positively affects employee brandoriented behaviour. Again, applying the same logic, it can be concluded that brand orientation can contribute to customers' engagement with a vendor's social media site. Based on the evidence above, the following hypotheses incorporate our expectations:

$\mathrm{H}_{1}$ : Brand orientation is positively associated with vendor's reputation.

$\mathrm{H}_{2}$ : Brand orientation is positively associated with social media site engagement. 


\subsection{Social Media Site Engagement (SME) and (e)WoM}

The radical revolution of Internet and its related technologies has created a new tool for individuals and businesses to network, engage and interact with each other (Leitner \& Grechenig, 2007; Wang, Xu, \& Chan, 2015; Zheng, Cheung, Lee, \& Liang, 2015). Social media technologies especially provide opportunities for business organizations to attract consumers and engage them in conversations on their social media platforms. Social media sites (SMSs) have been defined as web-based applications that help to generate profiles, upload pictures, videos and share with other people who are connected in the network (Boyd \& Ellison, 2007; Warren, Sulaiman, \& Jaafar, 2015). Social media platforms represent powerful tools for interaction and information sharing in general (Imran, 2014). On the part of vendors, they present tremendous opportunities for these brands to build an engaging relationship with their consumers via customer (fan)-brand followership. On the one hand, customers can use these tools to pass positive and negatives comments about brands. Chu and Kim (2011) noted that, consumers have employed SMSs such as Facebook, Qzone, MySpace, Instagram, Twitter, and Linkedln to create and share product related information with other consumers, consequently influencing their purchasing decision (HenningThurau, Gwinner, Walsh, \& Gremler, 2004; Wang \& Doong, 2010). This means that Social media sites are vitally important channels for (e)WoM. Some consumers, especially those that are highly price conscious, spend time seeking opinions from others in various online communities with regard to best prices, and subsequently share this information with other customers they engage with online and even in some instances via offline communication (Kang, 2007). This according to Harris and Dennis (2011) is one of the benefits of social websites. This is an indication that social media engagement can influence (e)WoM. Some studies (e.g. Walsh, Mitchell, Jackson, \& Beatty, 2009) have found that customers who are loyal and committed to some organizations support them through additional role behaviour. In this sense, these consumers are more likely not only to engage (by means of interaction) with their favourite vendor's brand social media fans' pages, but, more importantly, they are also likely to pass on positive comments about online retail vendors. Against this backdrop, the following hypothesis is formulated:

$\mathrm{H}_{3}$ : Social media site engagement is positively related to (e)WoM.

\subsection{Vendor Reputation (VRP), (e)WoM Effect and Repurchase Intention (RPI)}

From the resource-based view of the firm perspective, corporate reputation can be regarded as a valuable resource that can enable organizations to gain a lasting competitive edge (Capozzi, 2005). However, this will depend on how well the firm uses this reputation. Reputable vendors can influence their consumers to pass on favourable comments, which can lead others to buy from those vendors (Ahrens, Coyle, \& Strahilevitz, 2013; Xun, 2014). Consumers have positive attitudes towards reputable vendors and this results in a positive brand response such as passing on positive comments about the vendor, which in turn may lead to repeat purchasing among the online shoppers as well as customer patronage of some online retail vendors (Gupta, Melewar, \& Bourlakis, 2010; Maditinos \& Theodoridis, 2010; Huang, 2014; Soto-Acosta, Perez-Gonzalez, \& Popa, 2014). Additionally, Fombrun et al. (2000) and Sung and Yang (2008) assert that customers of well-reputed vendors engage in supportive behaviours. This is an indication that customers of reputable vendors will engage in (e)WoM for the vendors and patronise their brands. Lin, Lu and Wu (2012) examined the effect of corporate image and relationship marketing on trust and consumer purchase intention and found that corporate image significantly and positively impacts on consumers' purchase intentions; and word-of-mouth enhances this effect. From these findings, it is safe to conclude that vendors' reputation and (e)WoM influence shoppers' repurchase intentions online. Brengman and Karimov (2012) argue that, since it is difficult to assess intrinsic features of brands online, online shoppers may seek unbiased opinions in their purchasing decisions. Consequently, online product evaluation has become common among online consumers and a source of information for purchasing decision (Hu et al., 2008). In recent times, some vendors have employed and embraced social media in order to obtain consumer insights (Hudson \& Hudson, 2013), and use the opportunity to initiate 
(e)WoM. They do this by including a "tell-afriend" feature on their fan pages, or promoting online product ratings (Ahrens et al., 2013). Based on the foregoing arguments, these lead us to formulate the following hypotheses:

$\mathrm{H}_{4}$ : Vendor's reputation is positively associated with (e)WoM.

$\mathrm{H}_{5}$ : (e)WoM is positively associated with customers' repurchase intention.

\subsection{Vendor Reputation (VRP), Social Media Site Engagement (SME) and Repurchase Intention (RPI)}

Keh and Xie (2009) find that corporate reputation positively affects customer trust and customer identification, so for customers to engage and interact with a vendor will depend on how reputable the vendor is. Vendor reputation can have several outcomes. Brengman and Karimov (2012) note in their study that incorporating social media into corporate communication can influence customers towards unfamiliar e-tailers and "purchase intentions", but they caution that a vendor should only integrate appropriate and important ones. In an online environment, cues such as vendor's image information (Jin, Park, \& Kim, 2008) can instil trust and confidence in consumers and consequently they trust the online retailer (Wu, Chen, \& Chung, 2010; Wu \& Huang, 2015). However, Wu et al. (2010) note that this information might not be present when dealing with an unfamiliar e-vendor and therefore the initial trust formed would be based on the features of the vendor's site. Bennett and Gabriel (2001) assert that a positive corporate reputation gives customers consistent positive reinforcement, which commits them to the organization. Yoon, Choi and Sohn (2008) also shared a similar opinion with the aforementioned authors. Against the views that have so far been expressed in the literature, one may expect that the (perceived) vendor's reputation will play a leading role as to the online shopper's commitment to engage with the vendor's brand in social media platforms. Likewise, it seems very likely that the vendor's (perceived) reputation is even more important than ever before, as it is a critical determinant of customer patronage. In line with the above argumentation, we make the following hypotheses:

$\mathrm{H}_{6}$ : Vendor's reputation is positively related to social media site engagement.

$\mathrm{H}_{7}$ : Vendor's reputation is positively related to customers' repurchase intentions.

The set of relations is illustrated in Fig.1.

\section{Fig. 1: Research Model}

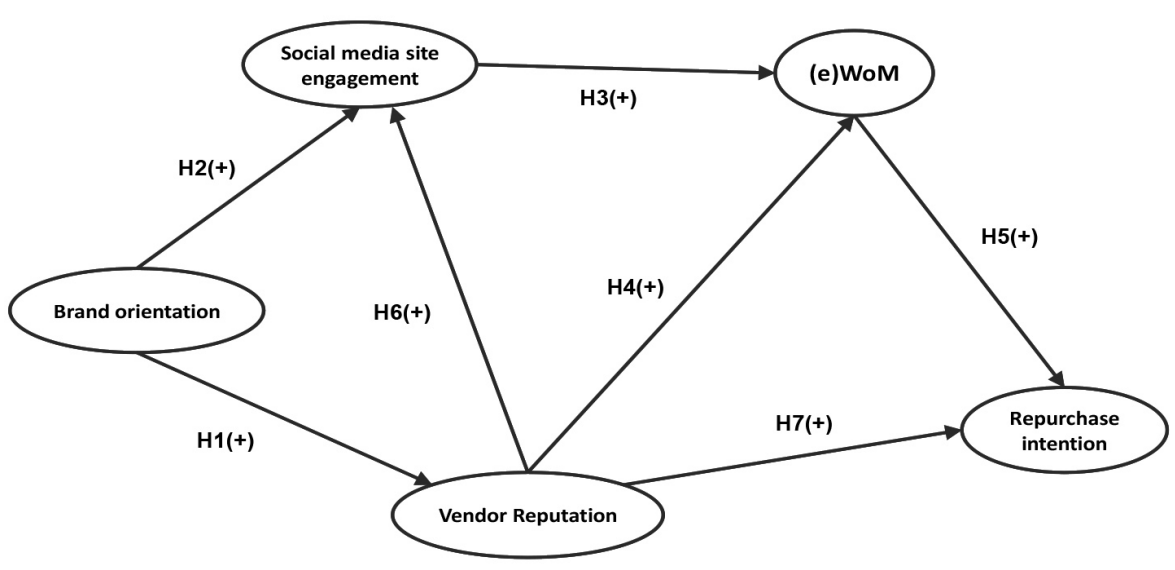

Source: own 


\section{Research Design}

\subsection{Sample and Data Collection}

The target respondents in our study were 'cosmopolitan' Slovak citizens. In this study, we defined cosmopolitan Slovaks as those who could write and speak in English. Thus, our unit of analysis is a bilingual (Slovak-English) speaker and at the same time a Slovak with Internet literacy. Accordingly, sample data were collected using a structured questionnaire and this was mainly despatched through an invitation to participate in a web-based survey. The survey link was also posted on some popular Facebook forums that are currently been utilized by Slovak nationals. To encourage participation, we assured the respondents of the confidentiality of their information and also made it explicitly clear that the research serves for academic purposes only. Data collection took place during the first and second quarters of 2014; in all, we were able to gather 125 effective responses from the study participants. Interestingly, nearly almost of the participants reported to have online shopping experience; and as might be expected most of the respondents were Slovak youths (see
Tab. 1 for further details about the participants). Importantly, our sample size exceeds the "ten times rule" for evaluating the suitability of a sample size used in a multivariate (regression) analysis (Costafreda, 2009; Detilleuxa, Theron, Beduin, \& Hanzen, 2012; Green, 1991; Hill, 1998; VanVoorhis \& Morgan, 2007). More specifically, the ratio of sample size to the number of parameters to be estimated in our research model is $25: 1$. From the sample data, we also found that nearly all the respondents use Facebook compare to few others who make use of any one of Twitter, Instagram, Linkeldn and Google+ (output omitted).

\subsection{Measures}

A five-point Likert scale, ranging from completely disagree (1) to completely agree (5) was used to elicit responses from the participants. All the measures used in the empirical survey were obtained from earlier studies and fully modified to remove any form of ambiguity from the items listed as part of the final scale. The measures for vendor reputation were adapted from Doney and Cannon (1997); Kim, Yang and Kim (2013) and Jarvenpaa, Tractinsky, and Vitale (2000),

\section{Tab. 1: Demographic profile of study participants}

\begin{tabular}{l|c|l|c}
\multicolumn{1}{c|}{ Gender: } & $\%$ & \multicolumn{1}{c}{ Internet Purchase: } & $\%$ \\
\hline Female & 64.8 & No & 4.8 \\
\hline Male Age Group: & 35.2 & Yes & 95.2 \\
\hline \multicolumn{1}{c|}{} & & \multicolumn{1}{c}{ Frequency of Internet Purchase: } & \\
\hline $17-25$ & 63.2 & Daily & 17.6 \\
\hline $26-34$ & 25.6 & Weekly & 42.9 \\
\hline $35-43$ & 7.2 & Monthly & 29.4 \\
\hline $44-52$ & 3.2 & Three or more times a year & 10.1 \\
\hline $53-61$ & 0.8 & Once or Twice yearly & - \\
\hline $61+$ & - & & \\
\hline & & \multicolumn{1}{|c}{ Patronage of Vendors' Website outside } & \\
\hline High School & 28 & No & 23.8 \\
\hline Undergraduate/Bachelor's & 29.6 & Yes & 76.2 \\
\hline Post Graduate (Master's, PhD) & 32.8 & & \\
\hline PhD/Professor & 8 & & \\
\hline Others & 1.6 & &
\end{tabular}




\section{Tab. 2: Reliability and convergent validity of measurement model}

\begin{tabular}{|c|c|c|c|c|c|c|}
\hline Constructs & $\alpha$ & CR & AVE & Indicators & FL & $\begin{array}{l}\text { Bootstrapped } \\
\text { T-Statistics }\end{array}$ \\
\hline \multirow{4}{*}{ BO } & \multirow{4}{*}{0.728} & \multirow{4}{*}{0.831} & \multirow{4}{*}{0.554} & BO1 & 0.714 & 7.484 \\
\hline & & & & $\mathrm{BO} 2$ & 0.789 & 8.968 \\
\hline & & & & $\mathrm{BO} 3$ & 0.816 & 9.609 \\
\hline & & & & $\mathrm{BO} 4$ & 0.645 & 4.815 \\
\hline \multirow{4}{*}{ SME } & \multirow{4}{*}{0.778} & \multirow{4}{*}{0.852} & \multirow{4}{*}{0.591} & SME2 & 0.711 & 4.084 \\
\hline & & & & SME3 & 0.693 & 3.429 \\
\hline & & & & SME4 & 0.785 & 4.547 \\
\hline & & & & SME5 & 0.875 & 5.089 \\
\hline \multirow{4}{*}{ VRP } & \multirow{4}{*}{0.725} & \multirow{4}{*}{0.828} & \multirow{4}{*}{0.547} & VRP1 & 0.705 & 8.031 \\
\hline & & & & VRP2 & 0.812 & 12.965 \\
\hline & & & & VRP3 & 0.706 & 7.067 \\
\hline & & & & VRP4 & 0.731 & 10.359 \\
\hline \multirow{4}{*}{ (e)WoM } & \multirow{4}{*}{0.735} & \multirow{4}{*}{0.834} & \multirow{4}{*}{0.557} & WoM1 & 0.686 & 11.479 \\
\hline & & & & WoM2 & 0.751 & 13.257 \\
\hline & & & & WoM3 & 0.771 & 13.262 \\
\hline & & & & WoM4 & 0.774 & 16.424 \\
\hline \multirow{4}{*}{ RPI } & \multirow{4}{*}{0.849} & \multirow{4}{*}{0.898} & \multirow{4}{*}{0.690} & RPI2 & 0.844 & 22.863 \\
\hline & & & & RPI3 & 0.880 & 28.997 \\
\hline & & & & RPI4 & 0.901 & 43.600 \\
\hline & & & & RPI5 & 0.680 & 7.788 \\
\hline
\end{tabular}

Note: Insignificant items are dropped (SME1 and RPI1)

while the items measuring the construct of brand orientation were adapted from Ling, Chai, and Piew (2010) and Seock (2003). The measures for (e)WoM effect were obtained from Awad and Ragowsky (2008), Mikalef, Giannakos, and Pateli (2013) and Zeithaml, Berry, and Parasuraman (1996). The items measuring social media site engagement with vendor brands were based on Karakaya and Barnes (2010), Laroche, Habibi, Richard, \& Sankaranarayanan (2012), and Ramnarainand and Govender (2013). The repurchase intention construct was adapted from Bhattacherjee (2001), Mathieson (1991), and Thong, Hong, and Tam (2006). Constructs and associated indicators in the measurement model are listed in the Appendix.

\subsection{Common Method Bias (CMB)}

Since we used a self-reported questionnaire study, we checked for CMB in the collated dataset. Based on the suggestion of Podsakoff, MacKenzie, Podsakoff, and Lee (2003), we ran a post-hoc statistical analysis of the surveyed data by means of Harman's unrotated single factor technique, using the principal component analysis (PCA) toolbox in SPSS. Our results show that the first dominant dimension accounted for a $21.6 \%$ variance. Furthermore, no single factor emerged from this unrotated factor analysis; all five distinct components had eigenvalues of greater than one. This hints at the absence of CMB in the surveyed.

\subsection{Psychometric Properties of Research Constructs}

First, we checked the internal consistency reliability of our measurement instruments by using Cronbach's alpha, manifest variables' loadings and composite reliability. From our output (see Tab. 2), all the constructs' 
Cronbach's alpha values are above the criterion value of 0.7 (Nunnaly, 1978). The manifest variables' loadings are within the range of 0.645 to 0.901 and are all statistically significant at the 0.01 level; about five items with insignificant loadings were purged out from the final analysis. Moreover, the composite reliability of each of the constructs is similarly above the suggested value of 0.7 (cf. Hair, Sarstedt, Ringle, \& Mena, 2012; Shahriar, 2014). In addition, the convergent validity of all the latent reflective constructs was checked by the average variance extracted (AVE), which are all above the commonly accepted threshold of 0.5 (cf. Rodriguez, Reina, \& Rufin, 2015).

Thereafter, we checked for discriminant validity of the measurement model using the approach suggested by Fornell and Lacker (1981). The results show that the square roots of the AVEs, which are in the diagonal cells (see Tab. 3) exceed the inter-correlations between the reflective latent variables. To further confirm the discriminant validity of our constructs, we went ahead by taking a look at the items' cross loadings. All the items were found to load differently on their assigned constructs and the average cross loading was about 0.2 (output omitted). To sum up, our measurement model shows that our research constructs have suitable reliability and construct validity. All the computations were carried out using the SmartPLS 2.0 (Ringle, Wende, \& Will, 2005) structural equation modelling software with a non-parametric bootstrap of 5,000 subsamples used to generate the T-Statistics. In this article, we opted to use PLS path modelling due to the exploratory nature of our study. Besides, we are mainly interested in the predictive validity of the research model given also our limited sample size. All these factors and even more warrant the use of PLS over the covariance-based SEM method.

\section{Tab. 3: Discriminant validity of measurement model}

\begin{tabular}{l|r|r|r|r|r|r|r} 
Latent Variables & \multicolumn{1}{|c|}{ Mean } & \multicolumn{1}{c|}{ SD } & \multicolumn{1}{c|}{$\mathbf{1}$} & \multicolumn{1}{c|}{$\mathbf{2}$} & $\mathbf{3}$ & $\mathbf{4}$ & $\mathbf{5}$ \\
\hline 1. SME & 2.949 & 0.818 & $\mathbf{0 . 7 6 9}$ & & & & \\
\hline 2. BO & 3.298 & 0.668 & 0.263 & $\mathbf{0 . 7 4 4}$ & & & \\
\hline 3. RPI & 3.483 & 0.726 & 0.167 & 0.106 & $\mathbf{0 . 8 3 1}$ & & \\
\hline 4. VRP & 3.933 & 0.661 & 0.093 & 0.256 & 0.266 & $\mathbf{0 . 7 4 0}$ & \\
\hline 5. (e)WoM & 3.830 & 0.348 & 0.192 & 0.161 & 0.457 & 0.484 & $\mathbf{0 . 7 4 6}$ \\
\hline
\end{tabular}

\section{Hypotheses Testing}

According to relevant studies (e.g. see Hair et al., 2012; Tenenhaus, Vinzi, Chatelin, \& Lauro, 2005), authors are expected to evaluate the inner model's coefficient of determination $\left(R^{2}\right)$, path coefficients, predictive relevance (StoneGeisser's $\mathrm{Q}^{2}$ ) of the model and its global Goodness-of-Fit (GoF) in order to assess the overall quality of the model. Based on the results, our research model is able to capture about $26 \%$ of the variance in (e)WoM effect and $21.2 \%$ of the variance in repurchase intention is captured in the research model. Please refer to Tab. 4 for more related information. In terms of the predictive relevance of the exogenous constructs, we used the blindfolding procedure (with omission distance, $d=7$ ). More specifically, we used the cross-validated redundancy measure (Stone-Geisser $\mathrm{Q}^{2}$ test) and all $\mathrm{Q}^{2}$ values for each of the endogenous constructs are positive values. Therefore, we can conclude that the predictive ability of the exogenous constructs is relatively stable and high. To assess the effect size of the overall global model, we used the GoF index (Tenenhaus et al., 2005). A GoF index value of 0.1 stands for a small effect size, 0.25 (GoFmedium) and 0.36 (GoFlarge) (cf. Osakwe \& Chovancová, 2015). We obtained a GoF index value of about 0.3 , which is considered as a slightly large effect size of $\mathrm{R}^{2}$, thus, indicating an adequate global validation of the overall PLS model (Wetzels et al., 2009).

Although the hypotheses were stated in a one-directional format, nevertheless, we used a two-tailed test (with a cut-off probability value, 


\section{Marketing a obchod}

\section{Tab. 4:}

\section{Results of the Path Modelling}

\begin{tabular}{|c|c|c|c|c|}
\hline \multicolumn{2}{|c|}{ IV $\rightarrow$ DV } & \multicolumn{2}{|c|}{ Path Coefficient } & $\begin{array}{c}\text { T-Statistics } \\
\text { (Bootstrapped) }\end{array}$ \\
\hline \multicolumn{2}{|l|}{ BO -> SME } & \multicolumn{2}{|c|}{0.286} & 2.498 \\
\hline \multicolumn{2}{|l|}{ BO -> VRP } & \multicolumn{2}{|c|}{0.283} & 2.979 \\
\hline \multicolumn{2}{|l|}{ VRP -> (e)WoM } & \multicolumn{2}{|c|}{0.471} & 5.518 \\
\hline \multicolumn{2}{|l|}{ (e)WoM -> RPI } & \multicolumn{2}{|c|}{0.429} & 5.088 \\
\hline \multicolumn{2}{|l|}{ SME-> (e)WoM } & \multicolumn{2}{|c|}{0.148} & 1.623 \\
\hline \multicolumn{2}{|l|}{ VRP $\rightarrow>$ RPI } & \multicolumn{2}{|c|}{0.059} & 0.857 \\
\hline \multicolumn{2}{|l|}{ VRP ->SME } & \multicolumn{2}{|c|}{0.028} & 0.291 \\
\hline \multicolumn{2}{|c|}{ Coefficient of Determination } & \multicolumn{2}{|c|}{ Cross-validated redundancy $\left(Q^{2}\right)$} & Model's GoF \\
\hline$R^{2}$ for $(e)$ WoM & 0.256 & $Q^{2}$ for $(e)$ WoM & 0.13 & \multirow{4}{*}{0.298} \\
\hline $\mathrm{R}^{2}$ for $\mathrm{RPI}$ & 0.212 & $\mathrm{Q}^{2}$ for $\mathrm{RPI}$ & 0.127 & \\
\hline $\mathrm{R}^{2}$ for $\mathrm{SME}$ & 0.070 & $Q^{2}$ for SME & 0.040 & \\
\hline$R^{2}$ for $V R P$ & 0.065 & $Q^{2}$ for VRP & 0.037 & \\
\hline
\end{tabular}

Source: own

$p<0.05$ ) to determine the statistical significance of our hypotheses. More importantly, the results (see Fig. 2 and Tab. 4) show that four out of the seven stated hypotheses were supported. Brand orientation is positively associated with a tendency to use social media sites to engage with vendors' brands $(\beta=0.286, p<0.01$ ). Also, consumers that are more brand oriented are more likely to have a higher perception of a vendor's reputation $(\beta=0.283, p<0.01)$. Moreover, a vendor's reputation was found to positively and to significantly contribute to

\section{Fig. 2: Empirical results}

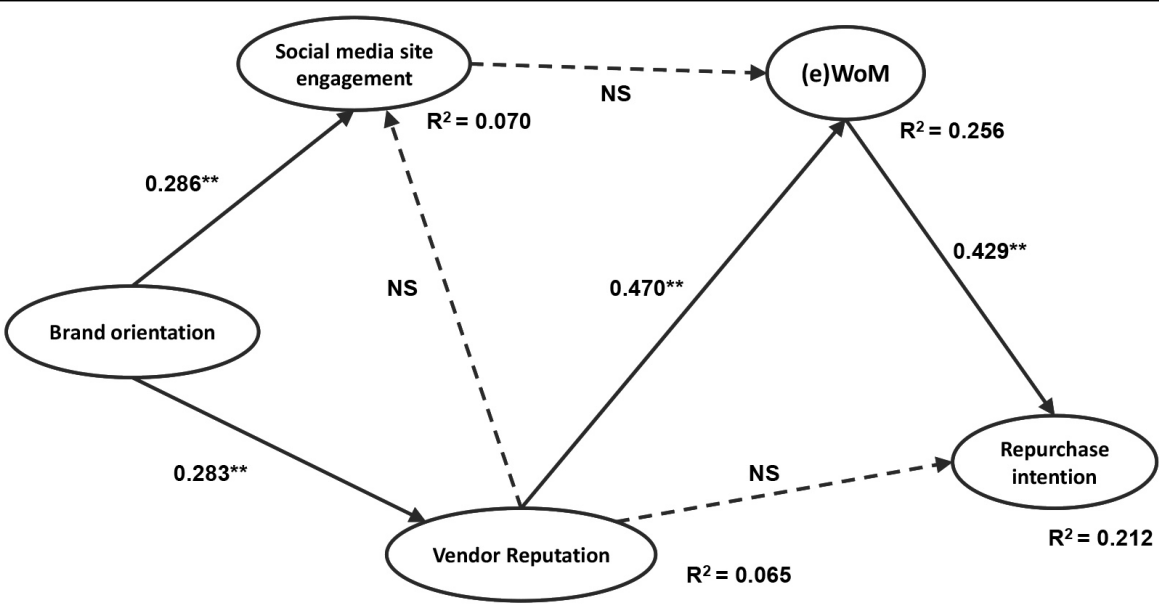

NS: Non-significant Path 
(e)WoM effect $(\beta=0.471, p<0.01)$. Similarly, (e)WoM effect is positively associated with online customers repurchase intentions $(\beta=0.429, p<0.01)$. On the other hand, social media engagement with a vendor's brand is positively related to (e)WoM effect, but it is not statistically significant $(\beta=0.148, p>0.05)$. Similarly, we found that VRP does not have any significant influence on SME $(\beta=0.028$, $p>0.05)$. This was equally the case with vendor reputation and repurchase intention $(\beta=0.059$, $p>0.05$ ). Just to briefly mention that a post-hoc analysis, though results not reported here due to space limitations, is indicative that (e)WoM is a mediator between VRP and RPI.

\section{Discussion of Findings}

The research offers empirical on the strong relationship between brand orientation and consumers engagement with vendors' social media site. This study contributes to the brand orientation literature while it also broadens our understanding of the broader subject area of relationship marketing at the same time. It finds that brand orientation leads to a higher perception of vendors' reputation online. Additionally, it finds that vendors' reputation has a significant effect on (e)WoM. Furthermore, the study confirms the significant effect of (e)WoM on repurchase intentions. Although the study found a relationship between consumers engagement with vendors' social media site, this was not substantial. Similarly, there was a relationship between vendors' reputation and consumers' engagement with vendors' social media site but it was not significant. Although, vendors' reputation was found to positively influence online shoppers' repurchase intentions, we could not establish any statistical significance for the result.

As most shoppers (especially, brand oriented consumers) prefer to buy famous brands online (Hutter et al., 2013), being brand oriented is one way of driving traffic and influencing consumers to engage with vendors' social media sites. As noted by Algesheimer et al. (2005) most consumers (very likely to be brand-oriented shoppers) prefer visiting and shopping on websites of well-known brands. Since most consumers are risk avert, especially when online, they will usually want to choose popular brands and therefore will shop most of the time on websites that are less risky. Consequently, once consumers find their preferred brand on a particular site, they stick to it (Hutter et al., 2013). In line with some existing studies (e.g. Sahin et al., 2011), this study found that brand orientation (on the part of online shoppers) creates a higher perception of vendors' reputation. In other words, brand orientation creates an impression in consumers' minds that a vendor is reliable and is trustworthy. The result suggests that this group of shoppers is more particular about the reputation of the vendor they buy from online because some online vendors do not keep to their promise and sell inferior brands. Consequently, some vendors spend more resources on building strong brands to distinguish themselves from the competition (Urde, 1999). The results in several ways align with the traditional thinking about the role that a brand plays in consumer decision-making, as a shopper's brand orientation has been established in the study to critically influence the shopper's interaction with the vendor's social platforms and this is also likely to make the consumer form an impression of the reputation of an online retail vendor.

Vendors' reputation as noted by Yoon et al. (2008) influences consumer behaviour. It is therefore not surprising that this study found a significant effect of vendors' reputation on (e)WoM. Consumers who buy from reputable vendors normally engage in product review online and support vendors by recommending them to other consumers online. Consumers who encountered and enjoy the services of reputable vendors talk to their friends and family about them. It is important to note that consumers do not only pass on good comments about vendors. Dissatisfied online shoppers are more likely to spread negative comments about vendors. As a result, having a good reputation online is highly essential for positive (e)WoM. In a similar vein, since 'most' consumers might not trust some of the online vendors; they are highly likely to rely on other consumers when making purchasing decisions. Consistent with Lin et al. (2012), this study found that (e)WoM affects repurchase intentions. This is probably because third party information source is seen to be more credible than information coming from an online retail vendor.

On the other hand, although this study found a positive relationship between customers engagement with vendors' social media site and (e)WoM, this relationship was statistically insignificant. This means that customers 
engagement with vendors social media site does not necessarily lead to (e)WoM. The vendors' website must contain credible information (Henning-Thurau et al., 2004) and provide users with relevant and timely information (Chu \& Kim, 2011). Additionally, contrary to some studies (Yoon et al., 2008; Bennett \& Gabriel, 2001), this study found an insignificant relationship between vendors' reputation and repurchase intentions. This is probably because the vendors' site lacks status information, which according to Jin et al. (2008) is very important in an online shopping environment. In the absence of this and other reputation cues on the site, consumers might not trust the vendor and therefore might not want to shop from the vendor (Wu et al., 2010). Again, it might be that the shoppers are not familiar with the online vendor (Wu et al., 2010). This study also found a positive relationship between vendors' reputation and customers' engagement with vendors' site; however, as mentioned earlier our finding was statistically insignificant. This is probably because the social media that the vendors are using are not appropriate and relevant to customers (Brengman \& Karimov, 2012). In this case, it is important that online vendors consider users' preference in their choice of social media.

\section{Conclusions}

This scientific paper has attempted to critically explore the dominant roles that online shoppers' brand orientation and vendors' reputation play in eMarketplace contex. Targeting brand-oriented consumers in the online retail environment would go a long way in building an enduring and an interactive customer-brand relationship in this particular setting since it has been shown in this study that BO positively affects SME. The findings have been underpinned with substantial evidence which shows that brandoriented shoppers are more inclined to engage with online retail brands across popular social media platforms. This implies that online retail brands should 'push' their product offerings via some of the popular social networking sites (SNSs) and, importantly, endeavour to keep track of those online users in the social media community who most likely have affinity towards their brands and/or other similar brands.

Furthermore, this study shows that BO directly affects VRP positively. That is, online shoppers that are more brand-oriented are more likely to be associated with a vendor's brand that has a good reputation in the (e)marketplace. Thus, it is important for online retailers to come to the understanding that the key to gaining a strong foothold in the eMarketplace is primarily based on consistently building a good reputation with the firm's target customer groups, especially those savvy and sophisticated customers who over time have been identified as brand-oriented shoppers. A good tool that can be used to identify and/or track brand-oriented shoppers is web analytics to track customers' purchase patterns. It is important for online retail managers to note that any significant 'failing' in a vendor's reputation is likely to be an irritant to their customers, especially the brand-oriented shoppers who are equally likely to be their valued and loyal customers.

From the above, it is also clear that VRP is a direct antecedent to (e)WoM effect. There is no gainsaying the fact that online retail managers that seek to have a positive (e)WoM must as a matter of priority and necessity deliver consistent service to their customers before they can be perceived and/or seen as reliable and trustworthy online retail merchants. It is important for an online retail merchant to assure customers that they would consistently deliver on their promises to their customers. In case of any breach in their contractual promise with their customers, a proviso should have been made known to the customer(s) prior to any service failure on the part of the web merchant. Online retail managers should not forget either the fact that (e)WoM effect is not only the cheapest means of gaining favourable popularity against the competition but is also an important source for a retailer to build a good brand followership and ultimately a good brand image in a virtual environment that has tilted a substantial amount of marketing power to the online shopper(s). Not too surprisingly, this study has empirically demonstrated that RPI is a direct consequence of (e)WoM. That is, online shoppers repurchase intention is positively associated with (e)WoM. Consequently, it is vitally important for online retail practitioners to encourage their customers and/or prospects to recommend their services to their associates and/or family members either through electronic channels or oral conversations. Also, web retailers should endeavour to collect customers' feedbacks via their websites and equally keep track of customers' ratings of their services 
in third-party product review sites. Online retail managers need not be too dismayed even when their services are receiving low product reviews, they should, rather, see this as a surmountable challenge to improve their overall service offerings to their customers.

Although in this study, we could not empirically establish the role of SME as a support for (e)WoM, this does not mean that online retail managers should not be bothered about building an engaging social media conversations with their various fans and/or customers. Not doing this alone would amount to losing focus of what the social media bring to businesses in terms of brand visibility and followership. Even though VRP might not significantly influence SME and RPI as reported in the current study, it is highly possible that VRP indirectly influences RPI through (e)WoM as this study has established an empirical link that stems from VRP to (e)WoM as well as from (e)WoM to RPI (see Tab. 4). Importantly, for VRP to significantly influence SME, online retail managers should find a way of directly bringing brand evangelists and/or social media 'info mavens' on board to their online conversations since it is this set of individuals that can really give more 'life' to a retail firm's social media engagement with online users. The result of a post-hoc analysis as was mentioned above suggests that (e)WoM may play an auxiliary role in terms of acting as a strong mediator between VRP and RPI (i.e. repurchase intention). This additional finding though not part of our initial set of hypotheses warrants further scrutiny in further research. We shall also revisit other future lines of research in the concluding sentences of this scientific article.

To conclude, and from a managerial perspective, this study has brought to the fore the roles that shoppers brand orientation and vendors reputation play in the online retail setting, and more particularly the case of the alleged Slovak cosmopolitan online retail shoppers. Although this is an exploratory research, the findings may still help online retailers to focus on contextual factors that are most relevant to increasing online shoppers' repurchasing frequency as well as word-ofmouth effect using either electronic or nonelectronic means. Despite the findings of the research, we can boldly point to three shortcomings of the research. First, due to the type of data that we have collected, that is cross-sectional data, the findings in this study are bereft of any form of causality. Thus, it is important for readers to know that the reported findings in this study are at best correlations. The second limitation of this study has to do with the fact that this study was situated in a single EU country, Slovakia. Hence, it is highly likely the study's findings may not be universally applicable to other EU countries and non-EU countries. Another important limitation has to do with the fact that in a bid to have a parsimonious model, we were unable to capture other relevant variables such as online customer service/support, bargain incentive(s), information quality, and consumers' attitudinal loyalty to a web retailer's brand which may likely influence the outcome variables - (e)WoM and RPI. Although, our choice of statistical modelling (i.e. PLS) compensates for the limited sample size, still it would have been better had we gotten a larger sample size; efforts were also made in this direction but it did not yield any significant success. Nonetheless, the few limitations and/or the challenges of the current study should be seen in light of future research opportunities. First, there is the potential to replicate the findings of the study in another country, especially in other Visegrad Group countries in the EU region, so as to extensively assess the validity of the research findings. Generally speaking, larger sample sizes could help explain some of the insignificant links in our research model (see Fig. 2). Next, authors should endeavour to incorporate other relevant variables that we were unable to capture directly in our research model. Also, future research may have to expound on the results of our study by conducting a longitudinal research design in order to capture the underlying dynamics of the constructs used in the study. In addition, future research should explore the moderating effect of online shoppers' brand orientation on the interrelationships between social network engagement, vendor's reputation, (e)WoM effect and brand loyalty. Finally, to improve the generalizability of the reported findings in this study, conducting a cross-country study will improve our general understanding of the research constructs vis-a-vis (cosmopolitan) consumers' behaviour in the eMarketplace context.

Acknowledgement: This work was to a degree supported by an internal grant from TBU in 
Zlin (IGA/FaME/2015/039) and by Fundación Cajamurcia.

\section{References}

Aarikka-Stenroos, L., \& Makkonen, H. S. (2014). Industrial buyers' use of references, word-of-mouth and reputation in complex buying situation. Journal of Business and Industrial Marketing, 29(4), 344-352. doi:10.1108/JBIM08-2013-0164.

Agustin, C., \& Singh, J. (2005). Curvilinear effects of consumer loyalty determinants in relational exchanges. Journal of Marketing Research, 42(1), 96-108. doi:10.1509/jmkr.42.1.96.56961.

Ahrens, J., Coyle, J. R., \& Strahilevitz, M. A. (2013). Electronic word of mouth: The effects of incentives on e-referrals by senders and receivers. European Journal of Marketing, 47(7), 1034-1051. doi:10.1108/03090561311324192.

Algesheimer, R., Dholakia, U. M., \& Herrmann, A. (2005). The social influence of brand community: Evidence from European car clubs. Journal of marketing, 69(3), 19-34. doi:10.1509/jmkg.69.3.19.66363.

Ambler, T., Bhattacharya, C. B., Edell, J., Keller, K. L., Lemon, K. N., \& Mittal, V. (2002). Relating Brand and Customer Perspectives on Marketing Management. Journal of Service Research, 5(1), 13-25. doi:10.1509/jmkg.69.3.19.66363.

Awad, N. F., \& Ragowsky, A. (2008). Establishing Trust in Electronic Commerce through Online Word of Mouth: An Examination across Genders. Journal of Management Information Systems, 24(4), 101-121. doi:10.2753/MIS0742-1222240404.

Bartikowski, B., \& Walsh, G. (2011). Investigating mediators between corporate reputation and customer citizenship behaviors. Journal of Business Research, 64(1), 39-44. doi:10.1016/j.jbusres.2009.09.018.

Bennett, R., \& Gabriel, H. (2001). Corporate reputation, trait covariation and the averaging principle - The case of the UK pensions mis-selling scandal. European Journal of Marketing, 35(3/4), 387-413. doi:10.1108/03090560110382084.

Bhattacherjee, A. (2001). An empirical analysis of the antecedents of electronic commerce service continuance. Decision Support Systems, 32(2), 201-214. doi:10.1016/ S0167-9236(01)00111-7.
Boateng, H. (2014). Customer knowledge management practices on a social media platform: A case study of MTN Ghana and Vodafone Ghana. Information Development, 32(3). doi:10.1177/0266666914554723.

Boyd, D. M., \& Ellison, N. B. (2007). Social Network Sites: Definition, History and Scholarship. Journal of ComputerMediated Communication, 13(1), 210-230. doi:10.1111/j.1083-6101.2007.00393.x.

Brakus, J. J., Schmitt, B. H., \& Zarantonello, L. (2009). Brand experience: what is it? How is it measured? Does it affect loyalty? Journal of marketing, 73(3), 52-68. doi:10.1509/jmkg.73.3.52.

Brengman, M., \& Karimov, F. P. (2012). The effect of web communities on consumers' initial trust in B2C e-commerce websites. Management Research Review, 35(9), 791-817. doi:10.1108/01409171211256569.

Capozzi, L. (2005). Corporate reputation: our role in sustaining and building a valuable asset. Journal of Advertising Research, 45(3), 290-293. doi:10.1017/S0021849905050324.

Chu, S. C., \& Kim, Y. (2011). Determinants of consumer engagement in electronic wordof-mouth (eWOM) in social networking sites. International Journal of Advertising, 30(1), 47-75.

Costafreda, S. G. (2009). Pooling fMRI Data: Meta-Analysis, Mega-Analysis and MultiCenter Studies. Front Neuroinformatics, 3(33), 1-8. doi:10.3389/neuro.11.033.2009.

Curras-Perez, R., Ruiz-Mafe, C., \& Sanz-Blas, S. (2014). Determinants of user behaviour and recommendation in social networks: An integrative approach from the uses and gratifications perspective. Industrial Management \& Data Systems, 114(9), 1477-1498. doi:10.1108/IMDS-07-2014-0219.

Detilleux, J., Theron, L., Beduin, J. M., \& Hanzen, C. (2012). A structural equation model to evaluate direct and indirect factors associated with a latent measure of mastitis in Belgian dairy herds. Preventive Veterinary Medicine, 107(3-4), 170-179. doi:10.1016/j. prevetmed.2012.06.005.

Doney, P. M., \& Cannon, J. P. (1997). An examination of the nature of trust in buyerseller relationships. Journal of Marketing, 61(2), 35-51. doi:10.2307/1251829.

Fombrun, C. J., Gardberg, N. A., \& Barnett, M. L. (2000). Opportunity platforms and safety nets: Corporate citizenship and reputational risk. Business and society review, 105(1), 85-106. doi:10.1111/0045-3609.00066. 
Fornell, C. G., \& Larcker, D. F. (1981). Evaluating structural equation models with unobservable variables and measurement error. Journal of Marketing Research, 18(1), 39-50. doi:10.2307/3151312.

Green, S. B. (1991). How many subjects does it take to do a regression analysis? Multivariate Behavioral Research, 26(3), 499-510. doi:10.1207/s15327906mbr2603_7.

Gupta, S., Melewar, T. C., \& Bourlakis, M. (2010). Transfer of brand knowledge in businessto-business markets: a qualitative study. Journal of Business and Industrial Marketing, 25(5), 395-403. doi:10.1108/08858621011058151.

Hair, J. F., Sarstedt, M., Ringle, C. M., \& Mena, J. A. (2012). An assessment of the use of partial least squares structural equation modeling in marketing research. Journal of the Academy of Marketing Science, 40(3), 414-433. doi:10.1007/s11747-011-0261-6.

Harris, L., \& Dennis, C. (2011). Engaging customers on Facebook: Challenges for eretailers. Journal of Consumer Behaviour, 10(6), 338-346. doi:10.1002/cb.375.

Henning-Thurau, T., Gwinner, K. P., Walsh, G., \& Gremler, D. D. (2004). Electronic wordof-mouth via consumer-opinion platforms: what motivates consumers to articulate themselves on the internet? Journal of Interactive Marketing, 18(1), 38-52. doi:10.1002/dir.10073.

Hill, R. (1998). What Sample Size is "Enough" in Internet Survey Research? Interpersonal Computing and Technology. An Electronic Journal for the 21st Century, 6(3-4), 1-10.

$\mathrm{Hu}$, N., Liu, L., \& Zhang, J. J. (2008). Do online reviews affect product sales? The role of reviewer characteristics and temporal effects. Information Technology and Management, 9(3), 201-214. doi:10.1007/s10799-008-0041-2.

Huang, L.-S. (2014). Trust in product review blogs: the influence of self-disclosure and popularity. Behaviour and Information Technology, 34(1), 33-44. doi:10.1080/0144929X.2014.978378.

Hudson, S., \& Hudson, R. (2013). Engaging with consumers using social media: a case study of music festivals. International Journal of Event and Festival Management, 4(3), 206223. doi:10.1108/IJEFM-06-2013-0012.

Hutter, K., Hautz, J., Dennhardt, S., \& Fuller, J. (2013). The impact of user interactions in social media on brand awareness and purchase intention: the case of MINI on Facebook. Journal of Product and Brand Management, 22(5/6), 342-351. doi:10.1108/JPBM-05-2013-0299.
Imran, A. M. (2014). Effects of PrePurchase Search Motivation on User Attitudes toward Online Social Network Advertising: A Case of University Students. Journal of Competitiveness, 6(2), 42-55. doi:10.7441/joc.2014.02.04.

Jalkala, A., \& Salminen, R. T. (2009). Communicating customer references on industrial companies Web sites. Industrial Marketing Management, 38(7), 825-837. doi:10.1016/j.indmarman.2008.04.009.

Jarvenpaa, S. L., Tractinsky, N., \& Vitale, M. (2000). Consumer trust in an internet store. Information Technology and Management, 1(1), 45-71.

Jayawardhena, C., Wright, L. T., \& Dennis, C. (2007). Consumer online: Intentions, orientations and segmentation. International Journal of Retail and Distribution Management, 35(6), 515-526. doi:10.1108/09590550710750377.

Jin, B., Park, J. J., \& Kim, J. (2008). Crosscultural examination of the relationships among firm reputation, e-satisfaction, e-trust, and e-loyalty. International Marketing Review, 25(3), 324-337. doi:10.1108/02651330810877243.

Kang, S. (2007). Disembodiment in online social interaction: Impact of online chat on social support and psychosocial well-being. CyberPsychology and Behavior, 10(3), 475-477. doi:10.1089/cpb.2006.9929.

Karakaya, F., \& Barnes, N. G. (2010). Impact of online reviews of customer care experience on brand or company selection. Journal of Consumer Marketing, 27(5), 447-457. doi:10.1108/07363761011063349.

Keh, H. T., \& Xie, Y. (2009). Corporate reputation and customer behavioral intentions: The roles of trust, identification and commitment. Industrial Marketing Management, 38(7), 732-742. doi:10.1016/j.indmarman.2008.02.005.

Keller, K. L. (2009). Building strong brands in a modern marketing communications environment. Journal of marketing communications, 15(2-3), 139-155. doi:10.1080/13527260902757530.

Kim, J., Yang, K., \& Kim, B. Y. (2013). Online retailer reputation and consumer response: examining cross cultural differences. International Journal of Retail and Distribution Management, 41(9), 688-705. doi:10.1108/ IJRDM-02-2012-0009.

King, C., So, K. K. K., \& Grace, D. (2013). The influence of service brand orientation 
on hotel employees' attitude and behaviours in China. International Journal of Hospitality Management, 34(September), 172-180. doi:10.1016/j.ijhm.2013.03.004.

Kotler, P., \& Pfoertsch, W. A. (2007). Being Known or Being One of Many - The Need for Brand Management for Business-to-Business (B2B) Companies. Journal of Business and Industrial Marketing, 20(6), 357-362. doi:10.1108/08858620710780118.

Laroche, M., Habibi, M. R., Richard, M.-O., \& Sankaranarayanan, R. (2012). The effects of social media based brand communities on brand community markers, value creation practices, brand trust and brand loyalty. Computers in Human Behaviour, 28(5), 1755-1767. doi:10.1016/j.chb.2012.04.016.

Leitner, P., \& Grechenig, T. (2008). Social networking sphere: A snapshot of trends, functionalities and revenue models. In Proceedings of LADIS international conference on web based communities (pp. 187-191).

Lin, T. M. Y., Lu, K.-Y., \& Wu, J.-J. (2012). The effects of visual information in eWOM communication. Journal of Research in Interactive Marketing, 6(1), 7-26. doi:10.1108/17505931211241341.

Ling, K. C., Chai, L. T., \& Piew, T. H. (2010). The Effects of Shopping Orientations, Online Trust and Prior Online Purchase Experience toward Customers' Online Purchase Intention. International Business Research, 3(3), 63-76. doi:10.5539/ibr.v3n3p63.

Maditinos, D. I., \& Theodoridis, K. (2010). Satisfaction determinants in the Greek online shopping context. Information Technology and People, 23(4), 312-329. doi:10.1108/09593841011087789.

Mathieson, K. (1991). Predicting user intentions: comparing the technology acceptance model with the theory of planned behaviour. Information Systems Research, 2(3), 173-91. doi:10.1287/isre.2.3.173.

Mikalef, P., Giannakos, M., \& Pateli, A. (2013). Shopping and Word-of-Mouth, Intentions on Social Media. Journal of Theoretical and Applied Electronic Commerce Research, 8(1), 17-34. doi:10.4067/S0718-18762013000100003.

Miyamoto, T., \& Rexha, N. (2004). Determinants of three facets of customer trust: A marketing model of Japanese buyersupplier relationship. Journal of Business Research, 57(3), 312-319. doi:10.1016/S01482963(01)00327-7.
Nunnally, J. C. (1978). Psychometric theory (2nd ed.), New York: McGraw-Hill.

Park, J., Lee, H., \& Kim, C. (2014). Corporate social responsibilities, consumer trust and corporate reputation: South Korean consumers' perspectives. Journal ofBusiness Research, 67(3), 295-302. doi:10.1016/j.jbusres.2013.05.016.

Osakwe, C. N., \& Chovancová, M. (2015). Exploring online shopping behaviour within the context of online advertisement, customer service experience consciousness and price comparison websites: Perspectives from young female shoppers in the Zlínský region. Acta Universitatis Agriculturae Et Silviculturae Mendelianae Brunensis, 63(2), 595-605. doi:10.11118/actaun201563020595.

Peng, K.-F., Chen, Y., \& Wen, K.-W. (2014). Brand relationship, consumption values and branded app adoption. Industrial Management \& Data Systems, 114(8), 1131-1143. doi:10.1108/ IMDS-05-2014-0132.

Podsakoff, P. M., MacKenzie, S. B., Podsakoff, N. P., \& Lee, J. Y. (2003). The mismeasure of management and its implications for leadership research. The Leadership Quarterly, 14(6), 615-656.

Ramnarain, Y., \& Govender, K. K. (2013). Social media browsing and consumer behaviour: Exploring the youth market. African Journal of Business Management, 7(18), 1885-1893. doi:10.5897/AJBM12.1195.

Ringle, C. M., Wende, S., \& Will, A. (2005). SmartPLS 2.0. Retrieved from www.smartpls.de.

Rodriguez, A., Reina, M. D., Rufin, R. (2015). Relationship Quality and Exhibitor's Performance in Leisure Trade Shows. E\&M Ekonomie a Management, 18(3), 129-143. doi:10.15240/tul/001/2015-3-012.

Sahin, A., Zehir, C., \& Kitapaci, H. (2011). The Effects of Brand Experiences, Trust and Satisfaction on Building Brand Loyalty; An Empirical Research On Global Brands. Procedia Social and Behavioral Sciences, 24, 1288-1301. doi:10.1016/j.sbspro.2011.09.143.

Seock, Y.-K. (2003). Analysis of Clothing Websites for Young Customer Retention based on A Model of Customer Relationship Management via the Internet (Doctoral dissertation). Virginia Polytechnic Institute and State University. Retrieved February 9, 2015, from http://scholar.lib.vt.edu/theses/available/ etd-10272003-150525/unrestricted/YKETD.pdf.

Shahriar, A. (2014). AModel of Factors Affecting Foreign Brand Trust. Journal of Competitiveness, 6(3), 20-31. doi:10.7441/joc.2014.03.02. 
Shi, S., \& Chow, W. S. (2015). Trust development and transfer in social commerce: prior experience as moderator. Industrial Management \& Data Systems, 115(7), 1182-1203. doi:10.1108/IMDS-01-2015-0019.

Soto-Acosta, P., Molina-Castillo, F. J., Lopez-Nicolas, C., \& Colomo-Palacios, R. (2014). The effect of information overload and disorganisation on intention to purchase online: The role of perceived risk and internet experience. Online Information Review, 38(4), 543-561. doi:10.1108/OIR-01-2014-0008.

Soto-Acosta, P., Perez-Gonzalez, D., \& Popa, S. (2014). Determinants of Web 2.0 technologies for knowledge sharing in SMEs. Service Business, 8(3), 425-438. doi:10.1007/s11628-014-0247-9.

Soto-Acosta, P., Popa, S., \& Palacios-Marqués, D. (2016). Social web knowledge sharing and innovation performance in knowledge-intensive manufacturing SMEs. Journal of Technology Transfer. doi:10.1007/s10961-016-9498-z.

Sung, M., \& Yang, S. U. (2008). Toward the model of university image: The influence of brand personality, external prestige, and reputation. Journal of Public Relations Research, 20(4), 357-376. doi:10.1080/10627260802153207.

Tenenhaus, M., Vinzi, V. E., Chatelin, Y.-M., \& Lauro, C. (2005). PLS path modeling. Computational Statistics and Data Analysis, 48(1), 159-205. doi:10.1016/j.csda.2004.03.005.

Thong, J. Y. L., Hong, S. J., \& Tam, K. Y. (2006). The Effects of Post-Adoption Beliefs on the Expectation-Confirmation Model for Information Technology Continuance. International Journal of Human-Computer Studies, 64(9), 799-810. doi:10.1016/j.ijhcs.2006.05.001.

Urde, M. (1999). Brand orientation:Amindset for building brands into strategic resources. Journal of marketing management, 15(1-3), 117-133. doi:10.1362/026725799784870504.

Urde, M., Baumgarth, C., \& Merrilees, B. (2013). Brand orientation and market orientation-From alternatives to synergy. Journal of Business Research, 66(1), 13-20. doi:10.1016/j.jbusres.2011.07.018.

VanVoorhis, C. R. W., \& Morgan, B. L. (2007). Understanding Power and Rules of Thumb for Determining Sample Sizes. Tutorials in Quantitative Methods for Psychology, 3(2), 43-50.

Walsh, G., Mitchell, V.-W., Jackson, P. R., \& Beatty, S. E. (2009). Examining the antecedents and consequences of corporate reputation: A customer perspective. British Journal of Management, 20(2), 187-203. doi:10.1111/j.1467-8551.2007.00557.x.

Wang, D., Xu, L., \& Chan, H. C. (2015). Understanding the continuance use of social network sites: a computer self-efficacy perspective. Behaviour and Information Technology, 34(2), 204-216. doi:10.1080/0144 929X.2014.952778.

Wang, H. C., \& Doong, H. S. (2010). Does government effort or citizen word-of-mouth determine e-Government service diffusion? Behaviour and Information Technology, 29(4), 415-422. doi:10.1080/01449291003639897.

Warren, A. M., Sulaiman, A., \& Jaafar, N. I. (2015). Understanding civic engagement behaviour on Facebook from a social capital theory perspective. Behaviour and Information Technology, 34(2), 163-175. doi:10.1080/0144 929X.2014.934290.

Wetzels, M., Schroder, G. O., \& Oppen, V. C. (2009). Using PLS path modeling for assessing hierarchical construct models: Guidelines and empirical illustration. MIS Quarterly, 33(1), 177-195.

Wu, I.-L., \& Huang, C.-Y. (2015). Analysing complaint intentions in online shopping: the antecedents of justice and technology use and the mediator of customer satisfaction. Behaviour and Information Technology, 34(1), 69-80. doi:10.1080/0144929X.2013.866163.

Wu, J. J., Chen, Y. H., \& Chung, Y. S. (2010). Trust factors influencing virtual community members: A study of transaction communities. Journal of Business Research, 63(9), 1025-1032. doi:10.1016/j.jbusres.2009.03.022.

Xin, J. Y., Ramayah T., Soto-Acosta P., Popa, S., \& Ping, T. A. (2014). Analyzing the use of the Web 2.0 for brand awareness and competitive advantage: An empirical study in the Malaysian hospitability industry. Information Systems Management, 31(2), 96-103. doi:10.1080/10580530.2014.890425.

Xun, J. (2014). Revisiting the two-stage choice model: an empirical study of consumer choice on brand website visits. Behaviour and Information Technology, 33(11), 1192-1207. doi:10.1080/0144929X.2013.872188.

Yoon, D., Choi, S. M., \& Sohn, D. (2008). Building customer relationships in an electronic age: The role of interactivity of E-commerce Web sites. Psychology and Marketing, 25(7), 602-618. doi:10.1002/mar.20227.

Zablah, A. R., Brown, B. P., \& Donthu, N. (2010). The relative importance of brands in modified rebuy purchase situations. 


\section{Marketing a obchod}

International Journal of Research in Marketing, 27(3), 248-260.

Zeithaml, V. A., Berry, L. L., Parasuraman, A. (1996). The Behavioral Consequences of Service Quality. Journal of Marketing, 60(2), 31-46. doi:10.2307/1251929.

Zheng, X., Cheung, C. M. K., Lee, M. K. O., \& Liang, L. (2015). Building brand loyalty through user engagement in online brand communities in social networking sites. Information Technology and People, 28(1), 90-106. doi:10.1108/ITP-08-2013-0144.

\section{Ing. Christian Nedu Osakwe}

Tomas Bata University in Zlin

Faculty of Management and Economics Department of Management and Marketing osakwe@fame.utb.cz
Henry Boateng, Ph.D. Candidate

University of Technology, Sydney

School of Communication

Henry.Boateng@student.uts.edu.au

Simona Popa, Ph.D.

University of Murcia

Department of Management \& Finance sp.popa@um.es

doc. Ing. Miloslava Chovancová, CSc. Tomas Bata University in Zlin

Faculty of Management and Economics Department of Management and Marketing chovancova@fame.utb.cz

Prof. Pedro Soto-Acosta, Ph.D. University of Murcia

Department of Management \& Finance psoto@um.es 


\section{Constructs \& indicators}

\section{Brand orientation}

BO2 - Most times, I prefer to buy a well-known brand from a web retailer

BO2 - The most popular brands are usually my first pick/choice

BO3 - I am particular about a good brand name while shopping online

BO4 - For me, buying a popular brand online is less risky

\section{Social media site engagement}

SME1 - I would prefer to buy from a website that I am connected to on a social network site-facebook, twitter, instagram, flicker, etc...

SME2 - I think it is good for an online seller to have a Facebook / Twitter/

Linkeldn / Google+ Page

SME3 - I would like my online shopping websites to keep me updated with latest sales/products on my social network sites

SME4 - To me, it's important that companies engage with their customers through social network sites

SME5 - On the whole, I follow the activities of the companies I like on social network sites

\section{Vendor Reputation}

VRP1 - I can only buy from an online vendor that is reliable

VRP2 - I prefer to deal with a trustworthy web merchant

VRP3 - I am more particular about the reputation of any Internet seller

VRP4 - I like a website which is truthful about its offers

\section{(e)WoM}

WoM1 - For me, online product reviews will influence my purchasing decision

WoM2 - My friends and I sometimes talk about our shopping experiences

WoM3 - If I like/dislike a product, I tell my friends and family members

WoM4 - I will easily recommend a good online shopping website to others

\section{Repurchase intention}

RPI1 - Given the convenience of Shopping on the Web, I will always use it

RPI2 - I will continually use the Web for my shopping needs

RPI3 - I have made some recent purchases online and would most likely buy more items online

RPI4 - I will continually use the Internet for my shopping

RPI5 - I see my use of Internet shopping increasing in the nearby future

\section{Literature support}

Ling et al. (2010); Seock

(2003)

Karakaya and Barnes

(2010);

Laroche et al. (2012);

Ramnarain and

Govender (2013)
Doney and Cannon

(1997); Kim et al. (2013);

Jarvenpaa et al. (2000)

Awad and Ragowsky

(2008); Mikalef et al.

(2013); Zeithaml et al. (1996)

Note: five-point Likert-type scales 


\title{
Abstract
}

\section{UNDERSTANDING COSMOPOLITAN CONSUMERS' REPEAT PURCHASING IN THE EMARKETPLACE: CONTRIBUTION FROM A BRAND ORIENTATION THEORETICAL PERSPECTIVE}

\author{
Christian Nedu Osakwe, Henry Boateng, Simona Popa, Miloslava \\ Chovancová, Pedro Soto-Acosta
}

As this scientific paper is positioned under the relatively big umbrella of relationship marketing; it thus makes a fruitful attempt to bridge the gap between scholarship and practice. Our overriding objective of this study was to explore critically the contribution of customers' brand orientation as well as other vital constructs such as social media engagement, (e)vendor reputation and (e)WoM on repeat purchasing intention amongst cosmopolitan consumers in eMarketplace context. Data were collected through a non-probabilistic sampling technique from cosmopolitan consumers in one of the EU-27 countries, Slovakia. Data was analysed using the Partial Least Squares structural equation modelling. This study modelled online consumers' repeat purchasing decision using constructs such as brand orientation, vendor reputation, vendors' social media site engagement. The study found that brand orientation leads to a higher perception of vendors' reputation online. The findings showed that a positive and significant relationship exists between brand orientation and consumers engagement with vendors' social media site. Furthermore, this study found that vendors' reputation has a significant effect on (e)WoM. Importantly, this study confirmed the substantial effect of (e)WoM on repurchase intentions. These findings imply that online retail brands should 'push' their product offerings via some of the popular social networking sites (SNSs) and, importantly, endeavour to keep track of those online users in the social media community who most likely have affinity towards their brands and/or other similar brands. By and large, the paper has demonstrated that the studied constructs are key in consumers' decision making online. Hopefully, the findings of the research will assist the online retail vendor in its execution of (robust) customer friendly policies.

Key Words: Social media engagement, (e)vendor reputation, brand orientation, (e)WoM, repurchase intention.

JEL Classification: L81, M30, M31, O33.

DOI: 10.15240/tul/001/2016-4-011 